spectra will be implemented shortly. Experimental spectra services are being offered, and searches by compound identity and structure will be accepted; spectra can be purchased from those held by the Centre. The Centre also has a substantial collection of specialized data relating to the methods of storage and retrieval of information, and in particular to the use of electronic and photo-electric methods. Documentation advisory services are now being offered, partly on the basis of this. The publications of the Institute for Scientific Information and the Chemical Abstracts Service can be obtained through the Centre. Application for membership of the Centre is open to organizations and individuals requiring research information (annual subscriptions are $£ 15$

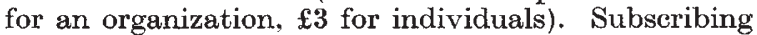
members receive substantial reductions in the charge for services. A publication, Spectra Index, listing the broad types of compound the spectra of which have been copied, is issued to members several times a year.

\section{Studland Heath National Nature Reserve, Dorset}

Studiand HFath, which covers the more southerly of the twin promontories almost barring access from Poole Harbour in Dorset to the English Channel, has been declared a National Nature Reserve by the Nature Conservancy. It is an intricate complex of sand-dunes, freshwater lagoons, lowland heaths and bog covering the seaward fringes of the ridges formed by the sandy Bagshot Beds. Its flora and fauna were the subject of a comprehensive biological survey begun in the 'twenties by Capt. C. Diver, the first director-general of the Nature Conservancy (1949-52). The establishment of this Heath as a National Nature Reserve was officially recommended in the Report of the Wild Life Conservation Special Committee (Cmd. 7122, July. London: H.M.S.O., 1947). This emphasized the overlapping at Studland of distributional limits of many south-eastern and south-western species and the educational importance of the 'diagrammatic' zoning of maritime, sub-maritime, dune, heath, marsh, freshwater and woodland vegetation types on acid soils. The Conservancy has leased 429 acres, including the freshwater lagoon called the Little Sea and the representative range of both old and younger sand-dunes except for their seaward frontage within a hundred feet of highwater mark. These, with the low-lying woodlands and marshes extending back to the Ferry Road and one detached bog with heathland to the west of the toll-gate, have been declared as the Studland Heath National Nature Reserve.

\section{Translocation of Game Animals in the Kruger National Park}

DURING recent years a number of scientists, game wardens and trappers have conducted investigations on the immobilization of game by means of a dartsyringe containing paralysing or hypnotic drugs. This is a completely new field of research for the veterinarian, the zoologist and the nature conservator, but its value and importance in nature conservation cannot be over-estimated. It enables the scientist to study the migration of game by marking suitable individuals, facilitates the transport and re-introduction of game into areas where they have become extinct, and makes possible veterinary research without the shooting of game. The Department of Nature Conservation of the National Parks Board of Trustees, Republic of South Africa, has recently initiated. research on the immobilization and transportation of game. J. W. Van Niekerk, State veterinarian, and Dr. U. de V. Pienaar, biologist, Skukuza, Kruger National Park, have described some of the results (Journal for Scientific Research in the National Parks of the Republic of South Africa, No. 5; 1962). Work was commenced on the blue wildebeest (Gorgon taurinus taurinus Burxhell) for the object of migratory studies, the impala (Aepyceros melampus melampus Lichtenstein) for physjological observations and diagnostic purposes in diseases, such as foot and mouth disease, and in the case of the hippopotamus (Hippopotamus amphibius capensis Linnaeus) for re-introduction to the Eastern Cape.

\section{The Atomic Gardening Society}

THE Atomic Gardening Society is a "scientific, educational, non-profit-making body" which carries out research on plant breeding using irradiated and chemically treated seeds and plants. Samples of seeds are exchanged between members and any variations which occur are recorded and, if possible, developed. The Society publishes a Digest, the latest issue of which contains information about chemical mutagens, radioactive irradiation of grain in the U.S.S.R., irradiation of African violets and peas and lettuce treated in Sweden (3, No. 3; June 1962. Pp. 10. The Atomic Gardening Society. Dr. Thomas Gray, "Winnipeg", Winchelsea, Sussex, 1962).

\section{Sir Henry Tizard}

Mr. R. W. Clark, of 10 Campden Street, Kensington, London, W.8, writes to the Editor of Nature, stating that he is preparing a biography of the late Sir Henry Tizard (with approval of Sir Henry's family). The Tizard papers, to which he is being granted full access for use in the biography, are very considerable. He would, nevertheless, be grateful to hear from any readers who have reminiscences of Sir Henry's life and work, or who possess letters from him.

\section{Announcements}

Mr. WALTER Binaghi has been re-elected president of the Council of the International Civil Aviation Organization. The Council is the permanent governing body of the Organization, and is elected by the Assembly for a three-year term. Mr. Binaghi was first elected to the presidency of the Council in 1957.

A Conference on "Hydraulies and Fluid Mechanics", sponsored by the Faculty of Engineering, University of Western Australia, is to be held in Perth during December 6-13. Further information can be obtained from the Conference Convener, School of Engineering, University of Western Australia, Nedlands, Western Australia.

AN exhibition of plastics and machinery, entitled "Centenary of Plastics 1862-1962" and arranged by the North-Eastern Section of the Plastics Institute, will be held at the Rutherford College of Technology, Newcastle upon Tyne, during November 6-10. Further information can be obtained from Mr. P. C. Oliver, 45 Worcester Way, Newcastle upon Tyne 1.

A symposium on "Recent Developments in Iron and Steel-making with Special Reference to Indian Conditions" has been jointly arranged by the Indian Institute of Metals, the National Metallurgical Laboratory (India) and the Iron and Steel Institute (U.K.) during February 4-8, 1963. Further information can be obtained from the Director, National Metallurgical Laboratory, Jamshedpur-7, India. 